\title{
State of the Art
}

\section{Historians and the Civil Rights Movement}

\author{
ADAM FAIRCLOUGH
}

What was the civil rights movement? When did it begin and end, and what did it achieve? As time distances historians from the events they study, periods that once appeared sharply defined become fuzzy at the edges, and changes that contemporaries thought sudden and profound seem less impressive than underlying continuities.

The popular "Montgomery to Memphis" time-frame brackets the movement with the leadership of Martin Luther King, Jr., 1955-68. In their search for origins, however, historians have traced the civil rights movement beyond Montgomery, beyond Brown v. Board of Education, and beyond even World War II. It was during the Great Depression, Harvard Sitkoff argues, that "the seeds that would later bear fruit" were planted; by 1940 blacks believed "that a new page in American history had been turned." According to Robert Norrell, the late 1930 s and I940s revealed "not just a few tantalizing moments of protest, but a widespread, if not yet mature, struggle to overthrow segregation and institutionalized racism." Robert Korstad and Nelson Lichtenstein place the beginning of the civil rights era in the labor radicalism of the early 1940s, "when the social structure of black America took on an increasingly urban, proletarian character," and half a million black workers joined CIO unions. During the 1940s, moreover, the NAACP increased its membership from 50,000 to 450,000 , growth that occurred mostly in the South. These years also saw blacks agitating for the ballot, founding political organizations, and, in the wake of $S$ mith $v$. Allwrigbt (1944) - a landmark decision ably documented by Darlene Clark Hine - becoming registered voters in significant numbers. ${ }^{1}$

Adam Fairclough is Senior Lecturer in History, St. David's University College, University of Wales, Lampeter, Dyfed, $\mathrm{SA}_{4} 8{ }_{7} \mathrm{ED}$.

${ }^{1}$ Harvard Sitkoff, $A$ New Deal for Blacks: The Emergence of Civil Rights as a National Issue (New York: Oxford University Press, 1978), 335; Robert J. Norrell, Reaping the Whirlwind: The Civil Rights Movement in Tuskegee (New York: Alfred A. Knopf, 1985), $\mathrm{x}$; Robert Korstad and Nelson Lichtenstein, "Opportunities Lost and Found: Labor, Radicals, and the Early Civil Rights Movement," Journal of American History, 75 (December 1988), 786-8I ; Darlene Clark Hine, Black Victory: The Rise and Fall of the White Primary in Texas (Millwood, NY: K.T.O. Press, 1979). 
It is tempting, therefore, to link the struggles of the I940s to those of $1955-65$, downgrading the conventional "turning-points" - Brown, Montgomery, and the student sit-ins - to mere sub-divisions of a larger whole. Raphael Cassimere, Jr., an historian and NAACP activist, has even suggested that the civil rights movement began "at least as early as the end of the nineteenth century," in protest against Plessy $\nu$. Ferguson. Looking at the other end of the period, Clayborne Carson has challenged the notion that "The civil rights movement died during the mid-i960s" to be displaced by a Black Power movement with dissimilar goals. In reality, argues Carson, local activists made no such distinction: the earlier movement to attain political rights evolved into a movement to exercise those rights; both comprised a larger "black freedom struggle seeking a broad range of goals." The trouble with such broad definitions, however, is that in stressing history's " seamless web" they turn history into a homogenized mush, without sharp breaks and transformations. "The people who were involved in the movement in the 1950 and 1960 s called it the civil rights movement," insists Hugh Murray. "Historians in pipe-smoke filled rooms ought not to try to rename it." In retaining the notion of a distinct civil rights movement, however, we need to ask: What made it a discrete "movement"? And what was its relationship to earlier and subsequent struggles? ${ }^{2}$

In explaining the emergence of the civil rights movement, the historical context is crucial. There is now a wealth of literature examining the late r93os and I940s. The NAACP's legal offensive against separate and inferior education, which began in 1935 and culminated in the 1954 Brown decision, has been explored in Richard Kluger's detailed study of the Brown cases, Genna Rae McNeil's fine biography of Charles H. Houston, and Mark V. Tushnet's trenchant analysis of the NAACP's legal strategy. ${ }^{3}$ Thanks to the work of Ralph Dalfiume, Lee Finkle, Neil A. Wynn, Harvard Sitkoff and others, the wartime years are no longer the "forgotten years" of the black struggle." William C.

2 Raphael Cassimere, Jr., "Equalizing Teachers' Pay in Louisiana," Integrated Education (July-August 1977), 3-8; Clayborne Carson, "Civil Rights Reform and the Black Freedom Struggle," in Charles W. Eagles (ed.), The Civil Rights Movement in America (Jackson: University of Mississippi Press, 1986), 19-37; Hugh Murray, "Change in the South," review essay, Journal of Ethnic Studies, 16 (Summer 1988), I 19-35.

${ }^{3}$ Genna Rae McNeil, Groundwork: Charles Hamilton Houston and the Struggle for Civil Rights (Philadelphia: University of Pennsylvania Press, 1983); Richard Kluger, Simple Justice: The History of Brown v. Board of Education and Black America's Struggle for Equality (New York: Alfred A. Knopf, 1976); Mark V. Tushnet, The NAACP's Legal Strategy Against Segregated Education, 1925-1950 (Chapel Hill: University of North Carolina Press, 1987).

4 Richard M. Dalfiume, "The 'Forgotten Years' of the Negro Revolution," Journal of American History, 55 (June 1968), 90-106, and Desegregation of the U.S. Armed Forces: Fighting on Two Fronts, 1939-1953 (Columbia: University of Missouri Press, 1969); Lee Finkle, Forum for Protest: The Black Press During World War II (Cranbury, N]: Associated University Press, 1975); Neil A. Wynn, The Afro-American and the Second World War (London: Paul Elek, 1976); Harvard Sitkoff, "Racial Militancy and Interracial Violence in the Second World War," Journal of American History, 58 (December 1971), 66I-81. 
Berman, Donald R. McCoy and Richard T. Ruetten have analyzed the emergence of black civil rights as a national political issue during the late 1940 s. ${ }^{5}$ A number of studies explore the challenge to white supremacy from southern liberals and radicals, as well as the more defensive, conservative positions of southern "moderates."

How then did the political currents of the Roosevelt-Truman years relate to the civil rights movement? Dalfiume, McCoy, and Ruetten view World War II and the early Truman years as a crucial period of black progress that underpinned all subsequent advances. I940 ushered in "a new age of race relations" because the war years decisively loosened the grip of white racism. But Sitkoff, Finkle, Burran, and Zangrando see no great breakthrough: blacks did not turn to A. Philip Randolph's program of mass nonviolent direct action; concessions like the Fair Employment Practices Commission proved meaningless; white supremacy and segregation remained intact; and the South retained sufficient political clout to kill FEPC, frustrate the NAACP's efforts to pass an antilynching bill, and wreck Truman's civil rights program. Wynn takes an intermediate position: blacks made clear gains during the war, but failure to build on that progress created a mood of frustration that eventually led to more militant tactics.?

Whatever the magnitude of black gains during the 1940s, it is clear that the Cold War ended one phase of the struggle. The politics of the Roosevelt era petered out in the late 1940s as anticommunist hysteria extinguished the Old Left, put liberals on the defensive, and strengthened the forces of conservatism. Yet historians of the civil rights movement have generally glossed over the impact of the Cold War. According to Manning Marable, Hugh Murray and Gerald Horne, McCarthyism suppressed a nascent civil rights movement by destroying organizations like the Southern Conference for Human Welfare, the Southern Negro Youth Congress, the Progressive Party, and the Civil Rights Congress.

5 William C. Berman, The Politics of Civil Rights in the Truman Administration (Columbus: Ohio State University Press, 1970); Donald R. McCoy and Richard T. Ruetten, Quest and Response: Minority Rights and the Truman Administration (Lawrence: University of Kansas Press, 1973).

6 Thomas A. Krueger, And Promises to Keep: A History of the Southern Conference for Human Welfare (Nashville: Vanderbilt University Press, i 967); Anthony P. Dunbar, Against the Grain: Southern Radicals and Prophets, 1929-1959 (Charlottesville: University of Virginia, 198 I); Morton Sosna, In Search of the Silent South: Southern Liberals and the Race Issue (New York: Columbia University Press, 1977); Charles W. Eagles, Jonathan Daniels and Race Relations: The Evolution of a Soutbern Liberal (Knoxville: University of Tennessee Press, 1982).

7 Dalfiume, "The 'Forgotten Years' of the Negro Revolution"; Wynn, 122-27; Donald R. McCoy and Richard T. Ruetten, "Towards Equality: Blacks in the United States During the Second World War," in A. C. Hepburn (ed.), Minorities in History (London: Edward Arnold, 1978), 135-53 (quotation on 136); Finkle, 221-23; Sitkoff, 675-81; James A. Burran, "Urban Racial Violence in the South During World War II: A Comparative Overview," in Walter J. Fraser, Jr. and Winfred B. Moore, Jr. (eds.), From the Old South to the New (Westport, CT.: Greenwood Press, I98I), 167-77; Robert L. Zangrando, The NAACP Crusade Against Lynching, 1909-19so (Philadelphia:

Temple University Press, I980), 201-13. 
And most historians, they allege, falsify history by tarring these groups as "Communist fronts," dismissing them as failures, or ignoring them entirely. The significance of these organizations has yet to be assessed but it may well be the case that historians have systematically underestimated their influence. ${ }^{8}$

The very failure of the Old Left, moreover, had enormous implications for the future of the black struggle. By collaborating with the anticommunist crusade the NAACP saw off rivals like the Civil Rights Congress and found itself in sole possession of the field; with nothing to buffer it on the left, however, it bore the full brunt of "Massive Resistance" to Brown, taking ten years to recover. The chilling effect of McCarthyism also meant that the civil rights movement that emerged between 1955 and 1960-partly in consequence of the NAACP's repression-divorced itself from the labor-oriented, class-based ethos of the predominantly white Old Left. But in separating the issues of race and economic class, the civil rights movement preempted McCarthyite attacks only to find itself without a program capable of addressing black poverty - a weakness cruelly exposed by the ghetto riots of the 1960 s. $^{9}$

The emergence of mass, nonviolent direct action signalled the start of a new phase of the struggle. In 1953 blacks in Baton Rouge, Louisiana, organized a short-lived bus boycott. Two years later, the Montgomery bus boycott began, and in 1956 a third boycott commenced in Tallahassee, Florida. Sociologist Doug McAdam has argued that the civil rights movement arose when southern blacks took the initiative and mobilized their own organizational resources rather than wait for outside support. Aldon D. Morris offers a similar analysis but with more supporting evidence. The bus boycotts, he argues, represented the genesis of a new black movement, indigenous to the South, based on independent local centers, and loosely organized around the black church. By banding these "movement centers" together in a loose alliance, the Southern Christian Leadership Conference (SCLC), organized in 1957, functioned as the "decentralized political arm of the black church." With the repression of the NAACP by state authorities, SCIC provided a flexible "infrastructure" capable of sustaining a regional mass movement. According to August Meier and Elliott Rudwick, however, the three main bus boycotts failed to spark off a southwide protest movement, and the Deep South of the r950s "was not yet a viable milieu for nonviolent direct action." The appearance of SCLC was certainly a milestone, but it failed to fulfill its initial ambitions and struggled to survive. Only with the student sit-ins of 1960 and the formation of the Student Nonviolent Coordinating Committee (SNCC)-developments largely independent of both the black churches and SCLC - did direct action surge across the South. ${ }^{10}$

8 Manning Marable, Race, Reform and Rebellion: The Second Reconstruction in America, 1945-1982 (London: Macmillan, 1984), 17-33; Hugh T. Murray, Jr., Civil Rights History-Writing and Anti-Communism: $A$ Critique (New York: American Institute for Marxist Studies, 1975); Gerald Horne, Communist Front? The Civil Rights Congress, 1946-1956 (Cranbury, NJ : Associated University Presses, 1988).

${ }^{9}$ Horne, 99, 140, 223-24; Dunbar, 258; Korstad and Lichtenstein, 8 I I.

10 Doug McAdam, Political Process and the Development of Black Insurgency, 1930-1970 (Chicago: University of Chicago Press, 1982); Aldon D. Morris, The Origins of the Civil Rights Movement: Black Communities Organizing for Change (New York: Free Press, I984); 
SCLC and SNCC played a large part in defining the new movement. Both were southern-based and black-led; neither adopted a mass membership structure along the lines of the NAACP, enabling them to avoid bureaucratic inertia but at the cost of instability and lack of formal democracy. SCLC and SNCC injected the struggle with youthful impatience, and they eschewed the NAACP's legalistic gradualism in favor of direct action involving (in theory if not always in practice) the "masses." The NAACP, with its older, more stable leadership and longer historical perspective, felt uncomfortable with the militancy of SCLC, SNCC and the revived Congress of Racial Equality; it also felt profoundly threatened by their mere existence. The NAACP found it difficult to identify with and adapt to this new phase of the struggle. Other organizations now forced the pace.

Memoirs and autobiographies help us to understand the character of these organizations and recall the spirit of the new movement. Three of the best come from former SNCC members. Following SNCC's demise, James Forman, its former executive secretary, wrote a long, angry, invaluable account of his experiences. Cleveland Sellers's 1973 memoir is heavily ghosted, which may partly explain its more reflective tone; it is nonetheless moving and informative. Mary King, one of SNCC's few white staff members, reminds us that she and others in SNCC helped stimulate the first stirrings of modern feminism; she also writes with particular insight and feeling about black-white relationships within SNCC. The autobiography of James Farmer recounts the experiences of a man who helped to found CORE in 1942, worked for the NAACP in the late 1950s, and served as CORE's national director during the glory years of the movement. Roy Wilkins's autobiography exemplifies the longer perspective of the NAACP: the author joined the Association's national staff in the r93os and headed the organization from the mid-1950s into the Reagan years. Of journalistic memoirs, Paul Good's account of his southern assignments in the mid-1960s is perhaps the most evocative. The memoir of Florence Mars is a rarity: an account of the Schwerner-Chaney-Goodman murders and their impact on Neshoba County of a white woman who, although born and bred in that Mississippi community, testified against the Klan. ${ }^{11}$

Given the prominence of Martin Luther King, Jr., the importance of nonviolent direct action, and the abundance of relevant sources, historians have tended to focus on King and the groups that were most committed to marching

August Meier and Elliott Rudwick, "The Origins of Nonviolent Direct Action in Afro-American Protest: A Note on Historical Discontinuities," in Along the Color Line: Explorations in the Black Experience (Urbana: University of Illinois Press, 1976), $307-404$.

11 James Forman, The Making of Black Revolutionaries (New York: Macmillan, 1972), 2nd edn. rev. (Washington, D.C.: Open Hand Publishing Inc., $x_{985}$ ); Cleveland Sellers and Robert Terrell, The River of No Return (New York: William Morrow, 1973); Mary King, Freedom Song (New York: William Morrow, 1987); James Farmer, Lay Bare the Heart (New York: Arbor House, $19^{8}$ s); Roy Wilkins, Standing Fast (New York: Viking Press, 1982); Paul Good, The Trouble I've Seen: White Journalist/Black Movement (Washington: Howard University Press, 1975); Florence Mars, Witness in Philadelphia (Baton Rouge: Louisiana State University Press, 1977). 
and going to jail. We have a comprehensive study of CORE by Meier and Rudwick, a workmanlike account of SNCC by Clayborne Carson, and a history of SCLC by this writer. There is no adequate history of the NAACP. However, the plodding character of the Association's national leadership, which has perhaps deterred historians, should not obscure the importance of the NAACP's local branches: future researchers may well find that in states like Louisiana and South Carolina the NAACP formed the backbone of the civil rights movement. Organizational history is thus by no means exhausted: there are large gaps, and the existing histories are not definitive. ${ }^{12}$

As for King, it might seem that Garrow's 8oo-page biography is the last word, but such a view would be misplaced. An impressive feat of research and scholarship - its command of the sources is unrivalled - Garrow's work attempts to let the facts speak for themselves, an approach that leaves the field wide open for alternative interpretations. Moreover, Garrow's own interpretation, which emerges through the welter of facts almost by default, has been criticized for misplaced emphasis and lack of coherence. Taylor Branch has attempted to combine a biography of King with a history of the civil rights movement. Weighing in at 1,000 pages, and ending in 1963 (a second volume is promised), Taylor's massive work suffers from prolixity and the journalist's fondness for anecdote; it is also well-grounded in the written sources. But it is superbly written, and its portrait of King is in some respects more sensitive and persuasive than Garrow's. Branch is particularly good on King's family background and student days. Other worthwhile books include Frederick Downing's analysis of King's personality and religious beliefs, which borrows from the development psychology of Erik Erikson, and studies of King's intellectual development by John Ansbro, Kenneth Smith and Ira Zepp. ${ }^{13}$

Some argue that the proliferation of King biographies, and the "top-down" approach generally, obscures the struggle "on the ground" whence the civil rights movement derived its dynamism. Recent years have thus seen a growth in local studies. These comprise two basic types: studies of particular protest campaigns that focus on brief periods : and studies of individual communities that trace developments over several decades.

12 August Meier and Elliott Rudwick, CORE: A Study in the Civil Rights Movement, 1942-1968 (New York: Oxford University Press, 1973); Clayborne Carson, In Struggle: SNCC and the Black Awakening of the 1960s (Cambridge: Harvard University Press, 1981); Adam Fairclough, To Redeem the Soul of America: The Southern Christian Leadership Conference and Martin Luther King, Jr. (Athens: University of Georgia Press, 1987).

13 David J. Garrow, Bearing the Cross: Martin Luther King, Jr. and the Southern Christian Leadership Conference (New York: William Morrow, 1986); Taylor Branch, Parting the Waters: America In the King Years, 1954-1963 (New York: Simon and Schuster, 1988); Frederick L. Downing, To See the Promised Land: The Faith Pilgrimage of Martin Lutber King, Jr. (Macon, GA: Mercer University Press, 1986); John Ansbro, Martin Luther King, Jr.: The Making of a Mind (Maryknoll, NY: Orbis Books, 1982); Kenneth L. Smith and Ira G. Zepp, Search for the Beloved Community: The Thinking of Martin Luther King, Jr. (Valley Forge, PA: Judson Press, 1974). See also Stephen B. Oates, Let The Trumpet Sound: The Life of Martin Lutber King, Jr. (London: Search Press, I 982); and Adam Fairclough, Martin Lutber Lutber King, Jr. (London: Sphere, forthcoming). 
In the first category we have histories of SCLC protests in St. Augustine, by David Colburn; Selma, by David Garrow; Chicago, by Alan Anderson and George Pickering; and Memphis, by Joan Beifuss. A major history of the Montgomery bus boycott is being completed by J. Mills Thornton and Ray Arceneaux (Thornton has already written a seminal article on the boycott). Some campaign studies have the quality of primary sources. Charles Fager, a former SCLC staff member, penned an account of Selma based on first-hand observation. Stephen Longnecker's book on Selma relies on the notes of Ralph Smeltzer, a white clergyman who attempted to mediate the conflict. The Jackson, Mississippi, movement of $1962-63$ has found a historian in John Salter, an NAACP activist who was in the thick of events there. ${ }^{14}$ The second category, the community study, includes works on Greensboro, by William Chafe; Tuskegee, by Robert Norrell; Birmingham, by Robert Corley; and New Orleans, by Kim Lacy Rogers (the last two are dissertations that have yet to be published). Frye Gaillard, Richard Pride and David Woodward have written studies of school desegregation that combine elements of both approaches: they have a longer perspective than campaign histories but a narrower focus than community studies. ${ }^{15}$

The community study, if properly handled, overcomes a major weakness of much civil rights historiography: the tendency to segregate history by race. Most histories have examined eitber white actions or black actions; only rarely have the twain met. Studies of Massive Resistance and southern politics have little to say about the civil rights movement. The only whites to appear in most histories of the civil rights movement are the Bull Connors and Jim Clarks. We need to marry the two perspectives: the civil rights movement involved a dialectic between blacks and whites. Neither side, moreover, was monolithic, and a study of this

14 David R. Colburn, Racial Change and Community Crisis: St. Augustine, Florida, 1877-1980 (New York: Columbia University Press, 1985), which, despite its title, focuses on the years $1963-64$; David J. Garrow, Protest at Selma: Martin Lutber King, Jr. and the Voting Rights Act of 1965 (New Haven: Yale University Press, 1978); Alan B. Anderson and George W. Pickering, Confronting the Color Line: The Broken Promise of the Civil Rights Movement in Chicago (Athens: University of Georgia Press, 1986); Joan T. Beifuss, At the River I Stand: Memphis, the 1968 Strike, and Martin Lutber King, Jr. (Memphis, B \& W Books, 1985); J. Mills Thornton, "Challenge and Response in the Montgomery Bus Boycott of 1959-1956," Alabama Review, 33 (July 1980), 163-235; Charles E. Fager, Selma 1965: The March that Changed a Nation (New York: Charles Scribner's Sons, 1974); Stephen E. Longnecker, Selma's Peacemaker: Ralph Smeltzer and Civil Rights Mediation (Philadelphia: Temple University Press, 1987); John R. Salter, Jackson, Mississippi: An American Cbronicle of Struggle and Schism (Hicksville, NY: Exposition Press, 1979).

15 William H. Chafe, Civilities and Civil Rights: Greensboro, North Carolina, and the Black Struggle for Freedom (New York: Oxford University Press, 1980); Norell, op. cit.; Robert G. Corley, "The Quest for Racial Harmony: Race Relations in Birmingham, Alabama, 1947-1963," Ph.D., University of Virginia, 1979; Kim Lacy Rogers, "Humanity and Desire: Civil Rights Leaders and the Desegregation of New Orleans, I $994-1966$," Ph.D., University of Minnesota, 1982; Frye Gaillard, The Dream Long Deferred (Chapel Hill: University of North Carolina Press, 1988); Richard A. Pride and J. David Woodward, The Burden of Busing: The Politics of Desegregation in Nasbville, Tennessee (Knoxville: University of Tennessee Press, 1985). 
dialectic enables us to escape from the stereotypes that have too often reduced history to a simple-minded morality play. Norrell and Chafe, for example, portray relationships both within each community and between each community with admirable sensitivity. ${ }^{\mathbf{1 6}}$

The growing popularity of oral history has also directed our attention toward local movements. In fact, oral history is relevant to every aspect of the civil rights movement - historians have interviewed federal judges, government officials, politicians, civil rights activists of every rank, and even members of lynch mobs. It is nonetheless true that oral history is especially useful for rescuing local struggles from comparative obscurity and exploring the role of "grass roots" activists who left little in the way of written documents. Historians can be led astray, however, if they neglect written sources or fail to treat their interviews critically, faults that have marred several otherwise excellent works. ${ }^{17}$

It would be a pity if in their enthusiasm for local studies scholars become afflicted by the historian's equivalent of "local people-itis" - the tendency of SNCC workers to romanticize and idealize the indigenous black poor. Emphasis on the purely local can lead to insularity and incoherence. Local struggles had a state, regional and national context, and these intersected in complex ways. Each state had a distinctive political culture - a fact long familiar to disciples of V. O. Key - which often affected the way local communities responded to black protest. Yet many historians of the civil rights movement have written as if state politics mattered little. State studies may offer a fruitful perspective that avoids the tendency of community studies to fragment our knowledge while retaining a sense of the movement's diversity and local roots. John Dittmer's forthcoming work on the civil rights movement in Mississippi will doubtless provide a yardstick for assessing the utility of this approach. ${ }^{18}$

16 The best studies of Massive Resistance are Numan V. Bartley, The Rise of Massive Resistance: Race and Politics in the South During the 1950s (Baton Rouge: Louisiana State University Press, 1969); Neil R. McMillen, The Citizen's Council: Organized Resistance to the Second Reconstruction (Urbana: University of Illinois Press, 1971); and James W. Ely, The Crisis of Conservative Virginia: The Byrd Organization and the Politics of Massive Resistance (Knoxville: University of Tennessee Press, 1976). Two works that do attempt to incorporate the black perspective are Glen Jeansonne, Leander Perez: Boss of the Delta (Baton Rouge: Louisiana State University Press, 1977); and Tom R. Wagy, LeRoy Collins of Florida: Spokesman of the New South (Tuscaloosa : University of Alabama Press, $1985)$.

17 Kim Lacy Rogers, "Oral History and the History of the Civil Rights Movement," Journal of American History, 75 (September 1988), ,67-76; Raines, My Soul is Rested: Movement Days in the Deep South Remembered (New York: G. P. Putnam's Sons, 1977) consists almost entirely of interview extracts. David J. Garrow's Bearing The Cross is perhaps the work that most successfully integrates extensive interviewing with mastery of the written sources. George Lipsitz, $A$ Life in the Struggle: Ivory Perry and the Culture of Opposition (Philadelphia: Temple University Press, 1988) is an interesting attempt to use both oral history and documents to analyze the civil rights movement from the viewpoint of an obscure activist.

18 Dittmer has anticipated some of his findings in "The Politics of the Mississippi Movement," in Eagles, $65-93$. 
Local struggles were also affected by national influences and institutions. As Steven F. Lawson has argued, the dichotomy between "local" and "national" is a false one: while independently-led local movements comprised the backbone of the black struggle, they could rarely pursue their goals effectively without reference to the federal government or without help from national organizations. For example, the Bogalusa Voters League, one of the most dynamic local movements of them all, sought assistance from CORE and the Lawyers Constitutional Defense Committee; it negotiated with the Crown-Zellerbach Corporation and the paper unions; and it achieved important court victories with the aid of the Department of Justice and Federal Judge Herbert W. Christenberry. ${ }^{19}$

The relationship between the civil rights movement and Big Business has aroused much scholarly interest. During the 1960s many liberals and some Marxists contended that industrialization and urbanization were gradually undermining the economic basis of white supremacy. As far back as $195 \mathrm{I}$, however, Samuel Lubell argued that industrialization, accompanied by systematic job discrimination, was marginalizing black labor and actually strengthening white supremacy. Comparing the Southern states with South Africa, John Cell and Stanley Greenberg found that racial segregation, far from being a preindustrial vestige, was actually a product of industrial capitalism. Community studies have found little evidence of southern businessmen actively promoting desegregation: as Tony Badger has argued in a review of recent research, the most that can be said is that businessmen comprised the weakest link in the segregationist chain. In some communities they reluctantly acquiesced in desegregation rather than face political and economic instability, but in others they abdicated all responsibility for preserving racial peace. Moreover, only the passage of the 1964 Civil Rights Act and continuing federal pressure induced nay compelled - businessmen to address their racist policies. ${ }^{20}$

It was pressure from the civil rights movement itself, of course, that prompted federal action against Jim Crow. Historians disagree, however, as to if, when, and why the federal government became the movement's active ally. The federal judiciary, for example, has been praised for its courage and leadership by Jack Bass, Charles Hamilton, Lucy McGough, and Frank Reed. J. Harvie Wilkinson and Mark Tushnet, on the other hand, accuse the judges of timidity and

19 Steven F. Lawson, "Commentary," in Eagles, 34-35.

20 Samuel Lubell, The Future of American Politics (New York: Harper and Row, 1951), I 8 8-20; Stanley B. Greenberg, Race and State in Capitalist Development: South Africa in Comparative Perspective (Johannesburg: Rowan Press, 1980); John W. Cell, The Highest Stage of White Supremacy: The Origins of Segregation in South Africa and the American South (Cambridge: Cambridge University Press, 1982); Elizabeth Jacoway and David R. Colburn (eds.), Southern Businessmen and Desegregation (Baton Rouge: Louisiana State University Press, I882); James C. Cobb, The Selling of the South: The Soutbern Crusade for Industrial Development, 1936-1980 (Baton Rouge: Louisiana State University Press, 1982); Steven M. Gelber, Black Men and Businessmen: The Growing Awareness of a Social Responsibility (Port Washington, NY: Kennikat Press, 1974); Tony Badger, "Segregation and the Southern Business Elite," Journal of American Studies, 18 (1 984), 105-9. 
inconsistency, arguing that judicial pronouncements had little impact until the upsurge of direct action in the early I 960 s produced strong federal legislation. ${ }^{21}$ Assessments of presidential performance are similarly divergent; Eisenhower, Kennedy and Johnson have been subjected to both sympathetic and critical analyses. It is exceedingly difficult, however, to judge their records by any "objective" standard: whether one concludes "should have done better" or "did quite well under the circumstances" seems largely a matter of the historian's philosophy and temperament. Historians have generally disparaged the civil rights record of Congress, although a few have dissected its operations with understanding if not sympathy. ${ }^{22}$ Perhaps the most useful means of judging federal performance is to study a single issue during several administrations, a method skilfully employed in Steven Lawson's studies of voting rights, Catherine Barnes's history of desegregation on trains and buses, and Michal Belknap's analysis of federal policy toward southern violence. ${ }^{23}$

The decline of racist violence is one of the least-noted aspects of the civil rights struggle. The notoriety of Jim Clark, Bull Connor, and the White Knights of the $\mathrm{Ku}$ Klux Klan obscures the fact that the violence inflicted upon the civil rights movement, although shocking, was mild compared to the vicious repression of fifty or even twenty years earlier. Lynching, common in the 1930 , became a rarity after the Second World War - partly a result of the anti-lynching crusades that have been studied by Jacquelyn Hall and Robert Zangrando. To appreciate the changed climate it is instructive to compare, for example, the 1934 lynching of Claude Neal, analyzed by James McGovern, with the 1959 lynching of Mack Parker, recounted by Howard Smead. In 1934 the Department of Justice refused to act on Neal's murder, even though the victim was kidnapped, transported

${ }^{21}$ Jack Bass, Unlikely Heroes (New York: Simon and Schuster, I98 1); Lucy S. McGough and Frank T. Read, Let Them Be Judged: The Judicial Integration of the Deep South (Metuchen, NJ: Scarecrow Press, 1978); J. Harvie Wilkinson III, From Brown to Bakke: The Supreme Court and School Integration, 1954-1978 (New York: Oxford University Press, 1979); Charles V. Hamilton, "Federal Law and the Courts in the Civil Rights Movement," and Mark V. Tushnet, "Commentary," in Eagles, 97-125.

${ }^{22}$ Generally critical : Robert F. Burk, The Eisenbower Administration and Black Civil Rights (Knoxville: University of Tennessee Press, 1984); Victor S. Navasky, Kennedy Justice (New York: Atheneum, 1971); John Herbers, The Lost Priority: What Happened to the Civil Rights Movement in America? (New York: Funk and Wagnalls, 1970) (Johnson); generally sympathetic: James C. Duram, A Moderate Among Extremists: Dwight D. Eisenhower and the School Desegregation Crisis (Chicago: 1981); Michael S. Mayer, "With Much Deliberation and Some Speed: Eisenhower and the Brown Decision," Journal of Southern History, 52 (February 1986), 43-76; Carl M. Brauer, Jobn F. Kennedy and the Second Reconstruction (New York: Columbia University Press, 1977). For Congress see Garrow, Protest at Selma; Charles and Barbara Whalen, The Longest Debate: A Legislative History of the 1964 Civil Rights Act (Cabin John, MD: Seven Locks Press, 1989).

${ }^{23}$ Steven F. Lawson, Black Ballots: Voting Rights in the South, 1944-1969 (New York: Columbia University Press, 1976), and In Pursuit of Power: Southern Blacks and Electoral Politics, 1965-1982 (New York: Columbia University Press, 198 s); Catherine A. Barnes, Journey from Jim Crow: The Desegregation of Southern Transit (New York: Columbia University Press, 1983); Michal R. Belknap, Federal Law and Southern Order: Racial Violence and Constitutional Confict in the Post-Brown South (Athens: University of Georgia Press, 1987). 
across state lines, and tortured to death by a Florida mob in a lynching that had been widely advertised beforehand. In 1959, by contrast, the Parker lynching in Mississippi prompted an FBI investigation involving 60 agents. By the 1950 , as Stephen Whitfield illustrates in his study of the earlier Emmett Till case, every lynching provoked national and international outrage. ${ }^{\mathbf{2 4}}$

The decline of overt violence, paradoxically, posed tactical problems for the civil rights movement. Mass nonviolent direct action could only have emerged in the context of growing restraint on the part of the white authorities, but that restraint indicated a shift to "legal" repression rather than any abandonment of white supremacy. And, as James Ely and Steven Barkan have argued, "legal" repression proved a most efficient method of stifling nonviolent protest. It was only by targeting and publicizing the most violent white supremacists that the civil rights movement found an effective counter-strategy that compelled federal intervention. It took the violence of Birmingham and Selma to produce effective civil rights laws, and the murder of civil rights workers in Mississippi and Alabama to prompt a crackdown on Klan terrorism. ${ }^{\mathbf{2 5}}$

What did the civil rights movement achieve? With a few exceptions, historians and political scientists are more likely to stress what it failed to achieve. School desegregation did not yield the social and educational dividends envisaged by its supporters, who often erased segregation de jure only to see it transmuted into segregation de facto. The integration of public accommodations has been far less significant than once thought. The enfranchisement of southern blacks has not upset white domination of state politics. A distressing number of blacks suffer from poverty, crime, drugs, and family breakdown. White racism still pervades society, North and South. And as its latest historian demonstrates, the $\mathrm{Ku}$ Klux Klan is alive and still deadly. ${ }^{26}$

24 Jacquelyn Dowd Hall, Revolt Against Cbivalry: Jesse Daniel Ames and the Women's Campaign Against Lynching (New York: Columbia University Press, 1979); Zangrando, The NAACP Crusade Against Lynching; James R. McGovern, Anatomy of a Lynching: The Killing of Claude Neal (Baton Rouge: Louisiana State University Press, 1982); Howard Smead, Blood Justice: The Lynching of Mack Charles Parker (New York: Oxford University Press, 1986); Stephen J. Whitfield, A Death in the Delta: The Story of Emmett Till (New York: Free Press, I988). See also Herbert Shapiro, White V'iolence and Black Response: From Reconstruction to Montgomery (Amherst: University of Massachusetts Press, 1988). Shapiro has promised another volume covering the 1960s.

25 James W. Ely, “Demonstrations and the Law : Danville as a Test Case," Vanderbilt Law Review, 27 (October 1974), 927-68; Steven E. Barkan, Protesters on Trial: Criminal Justice in the Southern Civil Rights and Vietnam Antiwar Movements (New Brunswick: Rutgers University Press, 1985 ).

${ }^{26}$ In addition to the works cited above, see Raymond Wolters, The Burden of Brown: Thirty Years of School Desegregation (Knoxville: University of Tennessee Press, 1984); Numan V. Bartley and Hugh D. Graham, Southern Politics and the Second Reconstruction (Baltimore: Johns Hopkins University Press, 1975); Alexander P. Lamis, The TwoParty South (New York: Oxford University Press, 1984); Wyn Craig Wade. The Fiery Cross: The Ku Klux Klan in America (New York: Simon and Schuster, 1987). For more optimistic (and journalistic) assessments, see Gaillard, The Dream Long Deferred; Jack Bass and Walter DeVries, The Transformation of Southern Politics (New York: Basic Books, 1976); Margaret Edds, Free at Last (New York: Adler and Adler, 1987). 
Writing in this Journal, George Rehin reviewed some of the recent books about the civil rights movement and assessed the present state of the subject's historiography. Clearly, there is much to be done. With their fondness for neat chains of cause and effect, historians have neglected the distinctive culture of the civil rights movement, and its subjective political, emotional, religious, and psychological dimensions. In a suggestive article, Richard King has stressed the need to understand how participation in the movement transformed the consciousness of individuals. Memoirs are drawing our attention to the substantial contribution that women made to the movement, both as leaders and supporters. We need to know more about the role of the churches, both black and white. The function of music and song cries out for analysis. ${ }^{27}$

Even within more traditional perspectives, there are large gaps. We are only beginning to understand how the FBI influenced the black struggle for good or ill. David Garrow and Kenneth O'Reilly have laid a solid foundation, but the staggering quantity of FBI documents potentially available through the Freedom of Information Act will keep historians occupied for many years to come. The NAACP is virtually uncharted territory, and the same is true of the NAACP Legal Defense Fund - incredibly, we have no adequate biography of that civil rights giant, Thurgood Marshall. We not only need more studies of school desegregation at the local level, but also a concise history of Brown's overall impact. Similarly, although historians will certainly add to our understanding of the civil rights movement in particular states and communities, a broad overview is sorely needed. Harvard Sitkoff, Manning Marable, Jack Bloom, and Robert Weisbrot have each written useful surveys - Bloom provides historical sweep, Marable polemical bite, Sitkoff and Weisbrot narrative verve. But none provides a balanced synthesis of the most recent scholarship. In the absence of the latter, the relatively short volume edited by Charles Eagles - a collection of conference papers - provides the most stimulating introduction to the subject. ${ }^{28}$

27 George Rehin, "Of Marshalls, Myrdals and Kings: Some Recent Books about the Second Reconstruction," Journal of American Studies, 22 (April 1988), 87-103; Richard H. King, "Citizenship and Self-Respect: The Experience of Politics in the Civil Rights Movement," ibid., 7-24; Doug McAdam, Freedom Summer (New York: Oxford University Press, 1988); David J. Garrow (ed.), The Montgomery Bus Boycott and the Women Who Started It: The Memoir of Jo Ann Gibson Robinson (Knoxville: University of Tennessee Press, 1987); Cynthia S. Brown (ed.), Ready From Within: Septima Clark and the Civil Rights Movement (Navarro, CA: Wild Trees Press, I986); Guy and Candie Carawan, "Freedom in the Air': An Overview of the Songs of the Civil Rights Movement"; Bernice Johnson Reagon, "The Lined Hymn as a Song of Freedom," both in Black Music Research Bulletin, 12 (Spring 1990), I-8.

David J. Garrow, The FBI and Martin Lutber King, Jr.: From "Solo" to Memphis (New York: W. W. Norton, I98 I); Kenneth O'Reilly, “Racial Matters": The FBI's Secret File on Black America, 1960-1972 (New York: Free Press, 1989); Harvard Sitkoff, The Struggle for Black Equality, 1954-1980 (New York: Hill and Wang, 198 I); Marable, Race, Reform and Rebellion; Jack M. Bloom, Race, Class, and the Civil Rights Movement (Bloomington: Indiana University Press, 1987); Robert Weisbrot, Freedom Bound: A History of America's Civil Rights Movement (New York: W. W. Norton, 1990); Eagles, The Civil Rights Movement in America. 